\title{
State-NGO Relations in Africa
}

\author{
Miriam Hofisi \\ North-West University, Department of Development Studies, \\ Costa Hofisi
}

North-West University, Department of Public Administration.

\section{Doi:10.5901/mjss.2013.v4n10p291}

\begin{abstract}
The objective of this article was to explore State-NGO relations and their impact on development in Africa. This article employs a historical approach in the analysis of state-ngo relations. While Africa is still riddled with abject poverty, the HIV-AIDS pandemic, tuberculosis, hunger and preventable diseases like cholera malaria and other chronic threats that call for help from other actors other than the government itself (Shah, 2009) the state itself has failed to address these problems and the NonGovernmental Organisations (NGOs) have for a long time attempted to fill that gap. However, in Africa, the relationship between the state and NGOs has been challenged by lack of mutual trust, while the proliferation of NGOs has not been met with political neutrality. We argue that given the fact that NGOs have had a significant impact in Africa, a partnership between the state and NGOs can realise sustainable development through working together. However, the state should provide a favourable environment for NGOs to operate and work in collaboration with the state in service provision in critical areas.
\end{abstract}

Keywords: Non-Governmental Organisations (NGOs), development, sustainability

\section{Introduction}

Africa is one continent that hosts a number of NGOs that work as development partners, the relationship between the host country and NGOs is the one that determines the scope which NGOs can reach. However, in Africa, the relationship between the state and NGOs has been challenged by lack of mutual trust Campbell (1996). In some instances, the state promulgates a plethora of legal instruments targeted at curtailing the activities of NGOs (Jalali, 2008). On the other hand, NGOs are accused of being responsible for foreign penetration based on allegations that they pursue political interests of their home countries or those of the international community as their agenda. At the same time NGOs also accuse governments of corruption, malgovernance and autocracy, pointing at these as the main factors that hamper development, thereby, justifying their existence.

It goes without saying that despite these challenges, Africa is still riddled with abject poverty. Africa has been classified as the poorest continent in the world. Its inhabitants are plagued by civil wars, the HIV-AIDS pandemic, tuberculosis, hunger and preventable diseases like cholera malaria and other chronic threats that call for help from other actors other than the government itself (Shah, 2009). According to Shah (2009) infectious diseases continue to blight the lives of the poor across the world of which the biggest chunk of the affected are in Africa. Sub-Saharan Africa alone accounted for an estimated $69 \%$ of all people living with HIV and $70 \%$ of all AIDS deaths in 2011. Every year there are 350-500 million cases of malaria, with 1 million fatalities. Africa accounts for $90 \%$ of malaria deaths and African children account for over $80 \%$ of malaria victims worldwide. Gibbs et al. (1999) also observe that the state itself has failed to address these problems. It is in the face of these alarming threats that NGOs came on the platform to help the poor. Some NGOs arose from within these plagued states while others came from European states as helpers.

NGOs remain relevant actors in developing countries because most of them offer assistance in critical areas like health, education, agriculture and other fields where the government cannot help (Tvedt, 1998). What is of concern is the relationship between states and NGOs in Africa which is lamented as a setback in the face of an afflicted people.

Mostly, NGOs are welcome where the state and government do not perceive them as threats. In some instances, the state will not be in a position to offer social services. A good example is that of war tone zones which often allow NGOs to offer relief services like food and shelter Cannon (2000). In other instances like in an autocratic state, NGOs that offer advocacy services tend to be viewed as political opponents hence they are unwelcome (Jalali, 2008). 
Therefore, the type of a regime in place plays an important role in giving or denying NGOs space. On the other hand NGOs tend to be reluctant to divulge information about their finances to government, however, government can introduce laws that ensure accountability on the part of NGOs (Moroso, 2005). Moreover, the government can control NGOs where they are perceived to be pursuing foreign agendas in the host country. However, the need for a partnership between these two can never be overemphasized given the background of growing poverty in Africa.

\section{How NGOs found their niche in Africa.}

The presence of NGOs in Africa dates back to the pre-colonial era where they provided social welfare services to those people who were neglected by the state. In the colonial era, NGOs found their niche in providing social services that the colonial state failed to offer (Michael, 2004). The colonial leaders had no commitment to finance state welfare programmes. Government social services for the blacks were minimal and social policy was geared towards ensuring the integrity of the structures of colonial rule. In fact, it was designed to secure a sufficient quality of labour to guarantee a reasonably efficient exploitation of the colony (Manji \& O'Coill, 2002).

These NGOs have long provided health and education services to the poor and they were best known as missionary society-based. Because they met with little opposition, these NGOs managed to offer services largely unhindered by the state if their role was not perceived as political opposition. In countries like South Africa, some NGOs that offered health services in the black homelands that were neglected by the state were not perceived as a threat to the state although at times they were subjected to state scrutiny. Largely, many local NGOs (especially church-based ones) played a significant role in ameliorating the misery of the poor.

\section{NGO-State relations in Africa: A historical overview.}

After the colonial period, Africans inherited authoritarian states that were primarily concerned with the extraction of revenue. This was due to the fact that the competitive nature of the colonial powers in contest for Africa required colonising nations to have a strong physical presence in their colonies to exclude rival powers (Michael, 2004). Such an ideology was maintained by the imposition of centralised and authoritarian state structures as an imperative. At independence, it was this autocratic and patrimonial extractive state that Africans inherited and maintained whose balance of power between the state and society was skewed towards the state.

As Michael notes, authoritarianism, coupled with socialism in Africa cemented the power of the state over society. Socialist leaders in most African countries expressed the need for pursuing a socialist ideology to improve the lives of the previously neglected poor people through equality of citizens (Michael, 2004). These needs were to be achieved through a single party state. The single party state was proclaimed as the embodiment of the socialist principles and as the return of these newly independent countries to egalitarianism which is seen as the traditional African form of governing. As a result, it is these ideologies that thwarted the good relations between the state and NGOs because under this type of regime, no organisation was supposed to exist outside of the state.

Furthermore, Michael writes that most governments feared the outbreak of civil wars along ethnic lines, hence they formed centralist states with the aim of taking total control of activities happening in their countries. Dispersed populations, ethnic, regional, religious or linguistic divisions posed serious threats to governments. These conditions made the governments to restrict pluralist activity. This monopolisation of political power reduced the ability of NGOs to obtain access to the state and state actors and to impact directly on the state decision making process. As a result, it allowed the government to increase its dominance in the lives of the people (Michael, 2004).

As the state continued to enjoy a certain degree of dominance, it introduced rural development programmes at community level for popular mobilization programmes such as Harambee in Kenya and Ujamaa in Tanzania (Michael, 2004). Initially, participation at grassroots level was high, however, as these programmes became highly politicised, participation waned and at the same time NGOs were dwindling in their numbers due to an unfriendly environment. Braathen \& Palmero (2001) in using Mozambique as an example, argue that the country inherited a state without civil society, and that when Frelimo took over, it maintained the legacy of their former coloniser. Frelimo, introduced initiatives called grupos dinamizadores (dynamizing groups) which were aimed at opening a channel for participatory development. Although the idea seemed brilliant, institutional impediments plagued this channel between the government and the people. Soon the idea was fraught with corruption and it was regarded as tools of the Frelimo party for dominance. Moreover, Frelimo had made itself a one party state hence the participation from other actors like NGOs was absent. 
Braathen \& Palmero (2001) further point out that lack of participation of NGOs in development emanates from the fact that the inherited state does not allow for participation of NGOs in policy formulation. Rather, policy formulation is heavily guarded as a highly political activity where NGOs are not supposed to come in. NGOs are only invited to come in and pursue what the government outlines. The authors posit that while most NGOs continue to play an important role in landmine activities, children's rights, health, and social reintegration for former combatants in Mozambique, NGOs are still marginalised by the government. There is lack of an entry point for NGOs due to some institutional stumbling blocks, for instance, the lack of participation of NGOs in policy formulation.

Mungate (1993) concurs with Braathen \& Palmero (2001) by stating that although the government in Zimbabwe recognises the role played by NGOs as important, there is lack of entry points and the government determines the scope and scale where NGOs can reach through institutionalisation of laws that do not allow participatory development. Although the above authors assume that the government recognises the importance of NGOs, it sounds like a political gimmick used by the politicians because they are the ones who are instituting the stumbling blocks that NGOs.

Michael, (2004) notes that the legacy of the state inherited by the post-colonial regimes which is reinforced by their subscription to African socialism has had a negative impact on the NGO-state relations in Africa. This resulted in the encroachment of a strong and bloated centralised government into NGOs and the resultant weakening and marginalisation of NGOs. The author further states that NGOs in Africa have been rendered weak and that this weakness is evident in the absence of material, organisational and ideological means required for NGO activity. NGOs lack the participation, coordination and leadership necessary to fulfil the organisational and ideological dimensions. The difficulties of planning and coordinating across competing ethnic, linguistic, and religious communities for instance have plagued the NGOs. In addition, there is lack of access to competent human resources. The tendency is that most qualified graduates prefer employment in governments or the private sector rather than in the NGOs. On this factor Michael concurs with Julie (2009) who has also observed that graduates prefer working somewhere else rather than with the NGOs. They can only work in NGOs if they do not have a choice. This is partly due to the fact that jobseekers often prefer long contracts unlike those of NGOs which are shorter.

It is not too far-fetched to argue that the efforts of the weak African states to consolidate their power led them to control and restrict NGO activities. This has had an effect on constraining the ability of African NGOs to develop capabilities needed to bring about development. Michael adds that NGOs in Africa, in particular Tanzania, Zimbabwe, Senegal and others reflect a lack of power to seriously assume a role in development. The author continues to argue that what is of paramount importance in this scenario is the fact that most African states never got the opportunity to offer their citizenry basic services in a sustainable and distributive manner.

It is against the background of this malgovernance by African states that the World Bank and IMF came up with structural adjustment programmes (SAPs) which were targeted at realising economic growth through deregulation of state enterprises, social welfare expenditure cutbacks and the globalisation of local markets. The argument behind SAPs was that government spending leads to economic inefficiency, hence the drastic reduction of government expenditure (Structural Adjustment Participatory Review International Network report, 2004). These reforms were geared to curb deficits and increasing revenues and also achieving large scale changes in the role of the state in the economy.

The core objective of SAPs was a radical shift away from the role of the state as a provider and guarantor of universally accessible social services to one of providing essential services in a targeted manner only to those on the margins. The reductions were said to be aimed at bringing about economic growth which would have "trickle down" effects to the poor thereby improving their lives. However, SAPs brought devastating results on the poor that further exacerbated their conditions. These effects of SAPs reduced state capacity to offer the little that they used to offer before. Therefore, it became apparent that NGOs were needed as important actors in development (Campbell, 1996).

Despite the fact that the state could not offer services to its citizenry, NGOs were not embraced as a partner for development by most governments. The state tried rather sluggishly to allow territorial access to NGOs, a process which is fraught with problems which still haunt their relations with the government to date.

\section{The different types of regimes under which NGOs operate in Africa.}

Swilling \& Russell (2003) came up with different regime types in their study of the scope of NGOs in South Africa comprising the liberal regime, the social democratic regime, the corporatist regime and the statist regime. Accordingly, these regime types have a role in determining the scope of NGO activity in a given environment. The liberal regime is characterised by low government expenditure on development, coupled with a well-developed non-profit sector. It grows 
under conditions where there is a strong middle class which prefers social development spearheaded by the non-profit sector.

The second type is the social democratic regime which has strong government expenditure on social development and a weak non-profit sector. This regime emerges in a state where there is a strong middle class that has gained political power to foster development. The social democratic state, to some extent resembles the South African state. The third type is the corporatist regime, where the state works with the non-profit sector to offer services to the people. This regime often arises where elites in power must accommodate NGOs. The form of states mentioned above resemble mostly the developed countries where most governments allow pluralist activities without fear that their legitimacy is at stake.

The fourth type of regime mentioned is the statist regime. This type of regime is characterised by low levels of social development expenditure, without the concomitant development of a non-profit sector with significant capacity to substitute for the state's neglect. This regime arises where there is an authoritarian state which is self-serving and faces no obligation to offer social services to the poor because most philanthropic activiiesy would have been thwarted in order to eliminate opposition.

In Zimbabwe, the attitude of the government towards NGOs soon after independence was that of mistrust, hostility, reticence and indifference. This kind of relationship can be attributed to the lack of knowledge of handling NGOs and was fuelled by political turbulence in some parts of the country. Moreover, the government had inclinations of a one party state. NGOs like Organisation of Rural Associations for Progress (ORAP) underwent considerable strain. Furthermore, the state's ideology of development which emphasised development planning by the state ran contrary to that of NGOs who stressed the participatory approach with little interference from the government.

Of importance to note is that in some developing countries the notion of sovereignty tends to be overemphasised, especially by autocratic leaders. This situation often happens where the legitimacy of the state is at stake. In such circumstances, NGOs are normally treated with suspicion and can be regarded as instruments of the enemy that seek to overthrow the government. Where the state suspects no threats and assured of its legitimacy, its relationship with NGOs usually works better.

For instance, in Zimbabwe during the early 1980s the government's legitimacy was at stake as was manifested by symptoms of civil wars. During that time the state treated NGOs with suspicion and NGOs underwent considerable strains. The government started to openly appreciate the role played by NGOs after its legitimacy was established when the Zanu PF government won the elections by majority in the late 1980s. In his speech, President R.G Mugabe said:

\begin{abstract}
A task of developing in Zimbabwe..... is an operation that must be tackled by the people themselves with government providing and/ harnessing all resources at its disposal. Government appreciates that NGOs can and do play a pivotal role in development, with the proper vision and approach and with good and open communication and collaboration with government; they can act as valuable partners in the development process. Silveira House has lived to this image for it has worked hard with the people for many years and has successfully built up a valuable grassroots network that readily facilitates further development.....(Mungate, 1993: 27).
\end{abstract}

Later in his speech the president quickly provided guidance on how NGOs should pursue development. This displays an element of mistrust whilst at the same time the government needed the help of NGOs. Mungate reiterates the same point when pointing out that the government lacked mutual trust in NGOs. This was also expressed by the late vice president Muzenda who raised the issue of security in 1987. In his speech, he gave a warning to NGOs that if they interfere with politics they will be subject to government intervention.

However, in some instances, NGOs are valued as partners when they complement government rather than substitute it. For instance, in Kenya, the Emergency Drought Recovery and Oxfam have become respected advisers to the government on community management of water and pastures in arid areas (Gibbs et al, 1999). Under such circumstances of sound relations, the government often acknowledges that NGOs have a comparative advantage.

Under an authoritarian regime, the government is more likely to restrict activist NGOs.

Although most states in Africa subscribe to international human rights movements and have even ratified some treaties like the Convention on the Elimination of all forms of Discrimination Against Women (CEDAW), the state still continues to limit mobilisation. States like Egypt, Tunisia and Yemen used the threat of Islamist terrorism to suppress human rights activists' access to international organisations and by instituting travel bans (Jalali, 2008).

Generally, dictatorships or single party states are often hostile to NGOs. The political history of Ethiopia also illustrates that NGOs under dictatorships experience a multiplicity of operational hurdles. When under Mengistu Haile Mariam's military regime, NGOs in Ethiopia were subjected to extreme state control of the government. They were not 
allowed to work in conflict areas. In addition to that, most projects were supposed to be registered with the Relief and Rehabilitation Commission (RRC) and then cleared by the relevant ministry. Their relationship was characterised by state repression and reticence. Since the Ethiopian government denied NGOs an opportunity to work with the people, the country was denied aid by donors on the account of human rights abuses. Aid donors preferred to fund NGOs to provide relief services only (Campbell, 1996).

However, state repression is not a phenomenon confined to the African continent, similar circumstances occurred when Prime Minister Indira Gandhi imposed emergency rule in

India. A number of NGO officials, political leaders and political activists were imprisoned. As a follow up, information about NGOs with foreign ties was demanded and in 1976 the Foreign Contribution Regulation Act (FCRA) was passed. The passing of the Act was supported by the argument that there was need to control foreign intervention that could destabilise the country (Campbell, 1996).

Moreover, when the Junata party in India got into power after two years in 1978, it was committed to restoring democracy but their efforts were short-lived because the Congress Party of Prime Minister Ghandi gained power again. When in power, Gandhi sought to increase insight into the activities of NGOs by instituting changes to the FCRA of 1976. A commission was set up to investigate misuse of funds and punitive measures were put in place to control NGOs. The relationship was characterised by hostility and suspicion. However, to show that a type of regime shapes the relations between the state and NGOs, when her son Rajiv Gandhi took over, he restored democratic principles. He also increased funding for NGOs and changed some restrictive sections of FCRA Act of 1976 (Jalali, 2008).

This shows that a transition from authoritarian to liberal democracy can also pose serious threats to the cooperation between the government and NGOs. As Campbell points out, when going through a transition, 'transaction costs' may hamper relations of NGOs and the state. There can be uncertainty of the nature and extent of political reform which can reduce prospects for cooperation. Even though the reform process may be intended for increasing political space for NGOs, conflict can arise as NGOs and the state flex out their muscles in the new political environment.

For instance, when going through a transition, many changes occurred in Ethiopia. NGOs grew in number from 60 to 250 as a result; a board was established to ensure cooperation between the state and NGOs. However, new challenges arose that jeopardised the state-NGO relations. The transition coincided with the implementation of SAPs. As the state became more sidelined by the SAPs, there was uncertainty at the central level about which state institutions are responsible for coordinating NGOs. At the grassroots level, the local government institutions were dismantled due to SAPs.

Consequently, the requirement to register with the Ministry of Justice made NGOs reluctant to enter into cooperation with the government. The NGOs complained that they were better off under the dictatorship than with the new democratic government. On the other hand, an increase in resources channelled to the NGOs also raised government's eyebrows who viewed NGOs as competitors because they expected funds to be channelled through the government (Campbell, 1996).

As Ethiopia settled politically, there was considerable evidence that NGO relations with the government had improved. By 1995, NGOs had come to accept that the government is entitled to coordinate NGO activities and to support the policy that promoted development. From the above illustration, one can observe that as democracy took root in Ethiopia, government legitimacy increased hence NGOs were not perceived as a threat. At the same time, NGOs finally realised that the new government did not mean any harm by requiring them to register. This goes to show that to a certain extent, mutuality between NGOs and the state can be established in an environment that is stable and democratic. Conversely, there are instances in the relationship between government and NGOs where governments can appreciate the willingness of NGOs to do unpopular things. Such areas include working with HIVIAIDS, control of sexually transmitted infections and prevention from parents to child transmission programmes. An example in this regard is that of the Kenyan government when they expressed their support for NGOs that work on these sensitive problems especially among the marginalised groups such as prostitutes and intravenous drug users (Gibbs et al. 1999).

At times NGOs are appreciated when they fill the gaps in the provision of essential services where the governments fail to provide. Jalali (2008) points out that in India, NGOs are becoming common and accepted mechanisms for the maintenance of public investments in rural water and sanitation systems in Maharashtra and Uttar Pradesh. However, in other instances, if NGOs provide services where the government is failing due to misuse of funds, the government tends to react in a harsh manner by using its power anyhow to drive out NGOs in fear of exposure to the international community. For instance, NGOs were not welcome under the Mengistu dictatorship in Ethiopia. However, with the outbreak of a major famine in 1983/5 NGOs started to flock in offering relief services. The state also seized the 
opportunity to show the international community that it was committed to assisting its people although it was mere political rhetoric.

From the above exposition it can be inferred that the relationship between governments and NGOs is a political question that impinges on the legitimacy of various types of institutions to exercise power. There is competition for who has the right to assert to leadership, to organise people, and to allocate resources in the development enterprise (Campbell, 1996).

NGOs can also come under criticism by changing their functions from service provision to advocacy. States can regard that as lack of adherence to the contract terms particularly in a repressive state. Emphasis is often given where NGOs would have gained access on the merit of their functions. For instance, after the drought in Ethiopia, the Mengistu dictatorship allowed NGOs to provide social development services only. However, a French NGO was expelled after it criticised the government for its resettlement policy (Campbell, 1996).

In other instances relations between the NGOs and the state can be plagued by lack of commitment from the side of the government. Cannon (2000) concurs with this point by giving an example of Uganda where NGOs assumed a leading role in providing services to the people while the government withdrew its own services. The staff of a Ugandan NGO called The Aids Support Organisation (TASO) expressed displeasure when they were told that "we the ACP are the brains and you TASO are our arms" by an official of the Aids Control Programme, a government organisation. A relationship like this does not boost morale for the NGO staff, neither does it promote development. Gibbs et al (1999) argues that at times NGOs help the state to put services within the reach of all through augmenting the initiatives of the state. Moreover, money withdrawn from offering services as intended can be embezzled by government employees.

On the other hand, NGOs can also be blamed for causing bad relations. An NGO in Uganda raised suspicions of government by refusing to divulge its financial matters to the government officials. The NGO was supported by the World Bank in its STI/AIDS programme. The Bank then advised the NGO to apply for funding through the relevant ministry. A potential source of tension was identified as the lack of transparency on the part of the NGO. District medical personnel in Uganda also expressed unhappiness due to the unwillingness of NGOs to share information about their budgets and work plans. A director of the Ugandan NGO further confirmed their unwillingness when he was quoted as saying 'we will tell the district about our activities, but we will discuss money only with those who gave us money'. Underlying these sentiments is the unanimous consensus of the NGOs to divulge information on their activities only. It is also under these circumstances that the government can begin to doubt the transparency of NGOs. Furthermore, a government can be offended by NGOs who by-pass relevant authorities in the implementation of their projects. In Uganda, an NGO that embarked on maternal child health operating in ten districts offended the ministry of health when it by-passed them. Although the NGO defended itself by arguing that the running of the project was under the management of the district officials, national government found it unbecoming.

In most Africa countries after the devastating effects of SAPs, NGOs took over the roles that used to be primarily the domain of the government. They operated through the state institutions or directly to the people. This has been referred to as the "internationalisation of public welfare" (Campbell, 1996). Tendencies of bypassing state institutions have been attributed to the disintegration of local governments under SAPs. This observation has been made by several authors, Campbell (1996:9) in quoting Palmer \& Rossitter (1990) argues that:

The state is withering away at a local level in countries such as Mozambique and Zambia, though not quite in the manner that Marx predicted. Gallantly stepping into the breach come the [northern] NGOs [NNGOs]... Whole districts or sections of once-functioning government ministries are handed over to foreigners to run, especially in health and social services. This process is enhanced as structural adjustment programmes bite ever deeper...

The more NNGOs are prepared to move in, the easier it becomes for governments to reduce support... But NGOs have notoriously short time frames; they are rarely able (even if willing) to commit themselves for more than 3 years ahead... The example of Mozambique is instructive. There, discovering an absence of (southern) NGOs, many NGOs responded by setting up their own operations, rather than working through the existing government structures... This clearly represents a process of institutional undermining rather than institution building... Surely it is a selffulfilling prophecy when NGOs then say that they are forced to become operational because of weak government structures. Governments have become increasingly suspicious of NGOs and this can lead to reticence. This behaviour often occurs when NGOs feel that they can replace the government through the services that they will be offering to the poor. According to Sinclair (1990) the idea that NGOs are more effective engines for social progress and economic development than government is almost universally popular and their importance have been popularised by international donors. At times this popularisation of NGOs shapes their behaviour whereby they undermine government authority. Under such circumstances friction is most likely to take place if the government feels threatened with the 
presence of NGOs because their existence, and the weakening of local government structures already poses a threat to the government.

\section{NGO-State relations: towards a sustainable partnership.}

Within this globalising world, the state has been made to share its power with other actors. These actors shape the agendas of the state in areas of rule of law, population policy, and policy for women's equality, technical standardization and environmental issues (Jalali, 2008). Other authors view this development as the process of dismantling the African state for the benefit of the powerful donors to plunder resources in Africa.

Jalali in quoting Matthews (1997) argues that national governments are not simply loosing autonomy in a globalising economy but they are sharing powers including political, social, and security roles at the core of sovereignty with NGOs. However, it must be stressed that NGOs evolved largely as a consequence of government's inability to provide social services. The dissatisfaction derived from the government's inability among the citizenry prompted the formation of community activism. This activism demands a degree of political power which is often times viewed as threatening to vested public sector interests by the government (Sinclair, 1990).

The relationship between the government and NGOs is complex as governments are often driven by a political agenda that often deviates from the strict priorities of development (Sinclair, 1990). When political interests take centre stage, NGOs are often explained away as instruments of the outsider. Major issues like poverty and hunger are often sidelined with governments complaining that their sovereignty is at stake. Under such circumstances, the government must allow other actors to help without totally losing its power.

In the developed states, the absence of NGOs can be explained in terms of a powerful state that can offer social services to its citizenry. In any case the history of some NGOs like Oxfam emanate from the post-world war period when most countries like Germany were experiencing an economic downturn. NGOs rose to help the poor until a point where the states managed to recover in terms of giving services to their people. Therefore, both actors have a role to play in as far as development is concerned.

The major role of the state includes giving a foundation of law, a friendly policy environment for NGOs, investment in people and infrastructure, protection of the vulnerable and protection of the natural environment (Clayton, 2007). It is the one that has the power to open up avenues for other actors to gain access to local people. Even locally mobilised groups should be recognised by local authorities to operate. According to Krasner in (Jalali, 2008), domestic structures (political culture, political institutions, and civil society) and the links between them not only determine the impact of NGOs but also influence their institutional structures. Multinational corporations also require the approval of the state to secure territorial access and their existence depends upon property rights that are created and maintained by states (Jalali, 2008). Therefore, a variety of state actors depend on the institutional structures of the host states for their functioning.

In addition, the state still possesses the power to protect its security. Most states still exercise control over their foreign policies with respect to defence as compared to issues concerning health or economies. Defence remains the ample domain of a state and protection of citizens and territory must exclusively remain under the control of the state. Similarly the issues concerning ethnic minority rights, given that they overlap with demands of territorial rights, are perceived by states as threatening to national interests in a manner that women's rights are (Jalali, 2008). Therefore, the involvement of NGOs in such areas should be treated with caution because serious questions of sovereignty will be at stake. For instance, although China and India differ in terms of domestic structures both of them do not allow foreign funding for minority groups such as Tibetans and Muslims respectively. This must not be interpreted as lack of NGO help but if territorial access puts the state's security at stake, the state tends to restrict funding towards that area (Jalali, 2008). Given the fact that NGOs do have resources, a partnership between the government and NGOs can realise sustainable development through working together. The task of the government should be that of providing a favourable legal environment for NGOs to operate and working in collaboration with NGOs in service provision in critical areas.

\section{References}

Braathen, E and Palmero, A. 2001 Towards a pro-poor government? The Case of Mozambique in Poverty Reduction. What role for the state in today's globalized economy edited by Kanji W and Braathen E. Cape Town, South Africa. NAEP.

Campbell, W. 1996 The potential for donor mediation in NGO-State relations: An Ethiopian Case study. Working Paper accessed from on www.ids.ac.uk 22/10/2009 
Cannon,C. 2000. NGOs and the state: a case study from Uganda in Development and Civil Society edited by Eade D. Oxford. Oxfam.

Clayton, A. 2007. NGOs, Civil Society and the State: Building Democracy in Transitional Countries. INTRAC NGO Policy and Management Paper Series (5), Oxford: INTRAC.

Gibbs, C.J.N, Funo, C. and Kuby, T. 1999, Nongovernmental Organisations in World Bank-Supported Projects. Washington D.C. USA. International Bank for Reconstruction and Development and World Bank.

Jalali, R. 2008. International Funding of NGOs in India: Bringing the State Back In in Voluntas Journal volume 19 pages 161-188 International Society for Third-Sector Research and The John Hopkins University accessed from www.springerlink.org on $12 / 09 / 2008$

Julie, F. 2009. The Roots of the NGO Crisis: A Look Beyond the Surface in NGO Pulse accessed on 05/10/2009 from www.ngopulse.co.za

Manji, F. and O'Coill, C. 2002. The Missionary Position: NGOs and Development in Africa. Blackwell. Britain.

Michael, S. 2004 Undermining Development The absence of power among local NGOs in Africa, African Issues: Oxford.James Currey.

Moroso, D 2005 The Role of NGOs in Africa: The case of Uganda. Crossroads volume 5 (1) accesed from www.webasa.org/Publicazioni/crossroads2004-1pdf on 08/10/2009

Mungate, D. 1993. Government Experience of Collaboration with NGOs In Agricultural Research and Extension in Non-Governmental Organisation and the State in Africa. Rethinking Roles in Sustainable Agricultural Development edited by Wellard K AND Copestake J.G. Routledge London.

Shah, A. 2009. Poverty Facts and Statistics on Global Issues accessed from www.globalissues.org/article/26/poverty-facts-and-stats on 23/10/2009.

Sinclair, M.R. 1990. Hope at last. A guide to Grantmaking in South Africa. Henry Kaiser Family Foundation. Washington D.C.

STRUCTURAL ADJUSTMENT: THE SAPRI REPORT, 2004. THE POLICY ROOTS OF ECONOMIC CRISIS, POVERTY AND INEQUALITY by The Structural A Participatory Review International Network. London. Zed books Ltd.

Swilling, M and Russell, B. 2003. The Size and Scope of the South African Non-Profit Sector. South Africa. Co-published by the Centre for Civil Society, the Graduate School of Public Development and Management University of Witwatersrand and University of Natal.

Tvedt, T. 1998. Angels of Mercy or Development Diplomats? NGOs and Foreign Aid. Trenton. Africa World Press. 